\title{
The Appearance of Awareness Related to Counter Intelligence in the Home Affairs Review in the Early 1960s
}

\section{A kémelhárító tevékenységgel kapcsolatos tudatosító tevékenység megjelenése a Belügyi Szemlében az 1960-as évek elején}

In the early 1960s, there were several events in the world and in Hungary that posed a decisive impact on the work of state security, including the field of counter intelligence. Political shifts in the socialist countries that began in the second half of the 1950s, including a confrontation with the former Stalinist system, the need to win over society in detecting crime, and the necessary broadening of relations between the two opposing blocs, all affected state security; also the reorganisation of the Ministry of the Interior (BM) in 1962, but also the rethinking of the professional journal of the Ministry of the Interior (Police Review) and its launch as the Home Affairs Review in 1963. The purpose of the present writing is to overview how those changes appeared in the articles of the Home Affairs Review with regard to one of the main areas of state security, the counter intelligence.

Keywords: state security, secret service, counter intelligence, awareness, Home Affairs Review

Az 1960-as évek elején több olyan esemény is történt a világban és Magyarországon, amely meghatározó volt a magyar állambiztonsági munka, azon belül is a kémelhárítás szempontjából. A szocialista országokban az 1950-es évek második felében elindult politikai irányváltás, többek között a korábbi, sztálini rendszerrel való szembefordulás, a társadalom megnyerésének igénye a büncselekmények felderítésében vagy a két szemben álló tömb kapcsolatainak szükségszerü kiszélesedése mind-mind hatással volt az állambiztonság feladatellátására. Szintén idesorolható a Belügyminisztérium 
(BM) 1962-es átszervezése, de a BM szakmai folyóiratának, a Rendőrségi Szemlének az újragondolása és Belügyi Szemleként történő 1963-as elindulása. Jelen írás célja annak áttekintése, hogy e változások hatásai hogyan jelentkeztek a Belügyi Szemle cikkeiben az állambiztonság egyik meghatározó területét, a kémelhárítási munkát érintően.

Kulcsszavak: állambiztonság, titkosszolgálat, kémelhárítás, biztonságtudatosítás, Belügyi Szemle

\section{Introduction}

By the 1960s, economic necessity forced European socialist countries to rethink and change their existing relations with the United States of America (USA) and the Western European countries. As a result, economic relations picked up and tourism started to grow dynamically.

In view of the international political situation, it was of paramount importance that in December 1962 the 'Hungarian affair' was removed from the United Nations (UN) agenda, and then in July 1963 the UN Secretary General, U Than, visited Hungary, which also had a positive effect on expanding international relations.

The widening of the existing interfaces between the countries of the two blocs provided an opportunity for the intelligence agencies to develop and increase their activities, and to take advantage of the opportunities created in this way. ${ }^{2}$ According to the Minister of the Interior, János Pap a significant change took place in the activities of foreign intelligence agencies: 'Previously, they tried to organize agencies and networks mainly by traveller agents. Now they are trying to use the outbound and inbound tourist traffic for this purpose.' ${ }^{3}$

The counter intelligence had to meet the challenges posed by these changes, and the political expectations placed on them.

The issue of intelligence appeared on the political stage several times in Hungary around the 1960s. In September 1958, there was a press conference in the Parliament on the József Karsai's case, who was spying for the Central Intelligence Agency (CIA) of the United States. They also used that press conference to 'protest against U.S. hostile policy, against the broadcasts of Voice of America, and Radio Free Europe'.4 In the early 1960s, János Kádár mentioned several times the importance of taking

2 P H, 'Polarizáció a nyugaton élő magyarság körében' [Polarisation among Hungarians Living in the West], Belügyi Szemle 1, no 10 (1963), 31.

3 László Szabó and János Pap, 'Adalék a rendőrség és a sajtó vitájához: lapjainkról nyilatkozik Pap János a Minisztertanács elnökhelyettese' [Addendum to the Debate between the Police and the Press: János Pap, Deputy Chairman of the Council of Ministers, Comments on our Papers], Belügyi Szemle 2, no 3 (1964), 76. Csaba Békés and Gusztáv D Kecskés (eds), A forradalom és a magyar kérdés az ENSZ-ben, 1956-1963: tanulmányok, dokumentumok és kronológia [The Revolution and the 'Hungarian Affair' in the UN, 1956-1963: Essays, Documents and Chronology] (Budapest: Magyar ENSZ Társaság, 2006), 43. 
action against spies ${ }^{5}$ and the need to condemn those involved in espionage. ${ }^{6}$ In order to settle relations with the UN, after the 1963 elections, 'the government proposed to the Presidential Council the issuance of a pardon decree'. In this connection, János Kádár stated that he did not see much possibility of using amnesty ${ }^{8}$ in the case of spies.

János Kádár also expressed his opinion: 'In addition to the first requirement of fidelity and unconditional devotion to the cause of socialism, the other, also indispensable requirement arises with increasing force: the competence, and the requirement of the necessary knowledge'. ${ }^{9}$

One of the practical consequences of this was that the previous professional and scientific journal of the internal affairs, the Police Review, was renewed along with the reorganisation of the Ministry of the Interior. The new journal, the Home Affairs Review, was considered a unified specialised journal of the Ministry of the Interior. According to the leadership of the Ministry of the Interior, the reason for its creation was that the party leadership 'demands a new style of work, a higher level of political and professional knowledge from the personnel of the Ministry'. ${ }^{10}$ Beyond conveying political ideas, the party leadership expected the Home Affairs Review 'to fight against outdated views, obscurant practices, faulty methods, and take a party-spirited stance on the introduction of those methods, procedures and modern technical tools in the wide range of home affairs work that are the results of scientific achievements and keep pace with our daily lives'. As expected, such an interface was created that was suitable for conducting professional dialogues and for transferring knowledge and good practices needed to solve certain tasks, regardless of space or time. ${ }^{11}$

Both the state security organisations ${ }^{12}$ and the Home Affairs Review ${ }^{13}$ were under direct and close party control. Consequently, the writings published in the Home Affairs Review during the period under examination reflect the party's position related to the Ministry of Defence, including state security work, the right orientations, tools and methods.

5 István Tímár, 'A Magyar Népköztársaság Büntető Törvénykönyvéről' [On the Criminal Code of the Hungarian People's Republic], Rendörségi Szemle 10, no 1 (1962), 12.

Országgyúlési napló [Minutes of Parliament], vol 1, 21 March 1963, 19.

„Kegyelmet kapnak bizonyos feltételek fennforgása esetén a háborús bűnösök is, a személyi kultusz éveiben a hatalommal visszaélő törvénysértők, az ellenforradalmi cselekményben búnösök, és olyanok is, akik az elmúlt legutóbbi hat évben követtek el államellenes bűncselekményeket. Kegyelmet nyernek azok is, akik az ország területét engedély nélkül hagyták el." [Provided that specific conditions are met, war criminals, those who misused power in the circumstances of personality cult, those who are guilty of taking part in the acts of counter-revolution, and those who committed treason in the last six years will be pardoned. Those who left the country without permission will also get pardon]. Országgyúlési napló [Minutes of Parliament], vol 1, 21 March 1963, 25.

8 Országgyúlési napló [Minutes of Parliament], vol 1, 21 March 1963, 540.

9 János Kádár's statement is from the report at the 8th Congress of the Hungarian Socialist Workers' Party (MSZMP). It was published in each number of the Home Affairs Review for two years.

10 János Pap, 'A „Belügyi Szemle” elé...' [Preface to the Home Affairs Review], Belügyi Szemle 1, no 1 (1963), 11. Ibid. 12.

12 István Kobolka, Nemzetbiztonsági alapismeretek [Fundamentals of National Security] (Budapest: Nemzeti Közszolgálati és Tankönyvkiadó, 2012), 17.

13 József Deák, 'A Belügyi Szemle közpolitikai, rendészetelméleti és szerkezeti fejlődése a rendszerváltásig' [Political, Theoretical and Structural Development of the Home Affairs Review until the Change of System], Hadtudományi Szemle 10, no 2 (2017), 345. 
The purpose of this paper is to examine which areas of counter intelligence and at what level considered the leadership of the party and of the Ministry of the Interior necessary to present in the Home Affairs Review as a reflection to the situation that had evolved by the early 1960s.

\section{The appearance of counter intelligence in the Home Affairs Review}

The statutory decree of the Presidential Council of the Hungarian People's Republic, Act No. 4 of 1963 on 'The Exercise of Public Pardon' was signed on 20 March 1963. The law provided that persons inter alia 'who have left the territory of the country since its liberation without permission, public pardon shall be granted'. ${ }^{14}$ One of the consequences of the decree, of the related legislation and of the political change behind, was that Hungarians living abroad could travel more easily or possibly repatriate. $^{15}$

Among the phenomena accompanying the 'policy of peaceful coexistence', ${ }^{16}$ the growth of tourism, together with the amnesty decree, broadened the possibilities of the intelligence agencies of Western countries. Thus, even those who did not sympathise with the system and had previously left the country could be sent to the territory of the Hungarian People's Republic as a representative of a business company, as a tourist, or as a relative. Here, these persons could even engage in intelligence activities (recruitment, contact, data collection). This option had significant advantages over the previous period. ${ }^{17}$ The 'peak traffic of international events (fairs, football matches, car races, etc.), the mass entry' also favoured the occasional entries. ${ }^{18}$

Moreover, the intelligence services also carried out talent-spotting activities among the growing number of Hungarian tourists ${ }^{19}$ and professionals ${ }^{20}$ traveling to the west. For that task they often employed research agents who had excellent command of Hungarian. ${ }^{21}$ The spotted person became a strong candidate, if he or she had an immediate relative in the west, ${ }^{22}$ he or she did not sympathise with the

$14 \quad$ A Magyar Népköztársaság Elnöki Tanácsának 1963. évi 4. számú törvényerejű rendelete a közkegyelem gyakorlásáról [The Statutory Decree of the Presidential Council of the Hungarian People's Republic, Act No. 4 of 1963 on "The Exercise of Public Pardon"], 1-2.

$15 \quad \mathrm{H}$, 'Polarizáció', 31.

16 The 20th Congress of the Soviet Communist Party held on 14-25 February 1956 gave up the theory of inevitable war and declared the possibility of peaceful coexistence with the capitalist world.

17 Gábor Gidáli, 'A hazalátogatás lehetőségével visszaélők néhány problémája és a BM szervek feladatai' [Some of the Problems of Those Who Abuse the Opportunity to Visit Home and the Tasks of Home Affairs Bodies], Belügyi Szemle 4, no 4 (1966), 18. Zs O, 'A kémügynök nyugatnémet turista' [The West German Tourist Spy], Belügyi Szemle 2, no 7 (1964), 102.

19 F K, 'A Bundes Nachrichtendienst „Tibet” fedőnevű ügynöke' [The Agent of the Bundes Nachrichtendienst under the Cover Name "Tibet”], Belügyi Szemle 2, no 8 (1964), 85.

20 I T and L R, 'Az amerikai hírszerzés „Horváth János” fedőnevű ügynöke' [The Agent of the American Intelligence under the Cover Name “János Horváth”], Belügyi Szemle 2, no 10 (1964), 75.

21 K, 'A Bundes Nachrichtendienst „Tibet” fedőnevű ügynöke', 85. 
system and was willing to take active actions against it, or possibly he or she used to be an employee or collaborator ${ }^{23}$ of an intelligence organisation before the war.

The territory of non-socialist European countries ${ }^{24}$ was an ideal platform for the recruitment of these individuals. There was less risk to accomplish the testing, the recruitment and the training of the candidates and there was no need to fear counter intelligence agencies.

Risks associated with the growth of tourism affected also other socialist countries. According to an article in the $14^{\text {th }}$ issue of Pogranichnik (Borderguard - a journal) in 1965, the U.S. and the FRG were engaged in significant intelligence activities in the Soviet Union, using the expanded economic relations and tourism. Tourists, scientists and students were involved in their activities. They saw scientific congresses, exhibitions and study scholarships as opportunities. In addition to the information gathering on military, politics, economy and recruiting, they were disseminating materials promoting the Western way of life and criticising the communist ideology. ${ }^{25}$

With the boom in tourism, changes took place also in the field of alien administration/immigration work. According to the professional opinion, in case of such a large number of entrants, '... it is already impossible ... and unnecessary, to control all the citizens entering or transiting the country, coming from a capitalist country'. The solution was found in increasing the efficiency of filtering and detecting. ${ }^{26}$ In order to facilitate the controlling activity, foreigners were allowed to stay in the country only with a permit. In case of a short term stay, their visa inside their passports served as a permit. This permit was issued by the National Central Authority for Controlling Aliens which also could prolong the permit. Foreign nationals had to check in within 24 hours of entering at the district or city police stations. The Police and district officials were obliged to oversee whether the check-ins had taken place. ${ }^{27}$

The fact that the citizens who emigrated during the 1956 revolution and in the subsequent period were interviewed by the staff of Western intelligence organisations in the refugee camps in order to obtain relevant military, political and economic information, as well as to spot the potential candidates for intelligence activity, had significant impact on counter intelligence activity. ${ }^{28}$ This partial-information obtained that way was used for the completion and correction of available data on the country and for carrying out certain intelligence operations. ${ }^{29}$ It happened that contacts and working relationships were established among the emigrant Hungarians, who later also took part in the recruitment of Hungarian citizens. ${ }^{30}$

24 T and R, 'Az amerikai hírszerzés „Horváth János” fedőnevű ügynöke', 76.

25 E Pincsukov, 'Turistáknak álcázott kémek: nemkívánatos vendégek: kivonatos közlés a „Pogranicsnik” 1965. évi 14. számából' [Spies Disguised as Tourists: Unwanted Guests: Extract from Issue 14 of 1965 of "Pogranichnik"], Belügyi Szemle 4, no 5 (1966), 120-124.

26 János Bozsik, 'A BM idegenrendészeti munkájának néhány problémája' [Some Problems of Immigration Work at the Ministry of the Interior], Belügyi Szemle 4, no 5 (1966), 18. Ibid. 19.

O, 'A kémügynök nyugatnémet turista', 97.

Ibid. 98.

Károly Józsa, 'Egy nyugatnémet kémügynök ügye' [The Case of a West German Spy], Belügyi Szemle 2, no 12 (1964), 81. 
Several case studies were presented during the examined period in the Review, as part of which several essential elements of intelligence activities were also presented. With regard to the future collaboration, the first step in establishing the relationship with the agent was to map his basic circumstances, which also included the person's 'lifestyle, political attitude, family circumstances, financial situation, and personal characteristics'. Hungarian tourists could spend only a limited period of time abroad, so there was limited time for establishing the relationship of trust, necessary to establish relationship with the agent. For this reason, the solution could be several, short time personal meetings. During the concrete invitation for the collaboration, the glorification of personal abilities, the trivialisation of the tasks and the work necessary to be performed, and emphasising the almost complete impossibility of being discovered were always part of the conversation. ${ }^{31}$ Sometimes, if the person did not agree, later someone else contacted him and tried to convince him to cooperate with the intelligence organisation. ${ }^{32}$ In some cases, the recruitment was done not on behalf of the particular intelligence agency, but for an international organisation to persuade the person more easily for the intelligence work. ${ }^{33}$ When the agent was recruited, he signed the statement of cooperation and the acknowledgment of receipt of the amount of money transferred for the cooperation, ${ }^{34}$ and he received his cover name. ${ }^{35}$

The following training of the agent included the information on agent handling, information on contacting, as well as the intelligence/information requirement. In most cases, the training included both theoretical and practical parts. Western intelligence agencies wanted to gain information through agents mostly about military objects and military equipment. ${ }^{36}$ In addition, it was often a task to identify individuals who could have been employed as agents. ${ }^{37}$ If the agent was debriefed personally, his reliability was also checked by using a polygraph/lie detector. ${ }^{38}$

For agent handling, the method of impersonal contact was used primarily due to the circumstances during this period. Therefore, the recruited agents had to be trained at the first meeting for at least one way of communication. One of the most commonly used practice for transmitting information to one and other were the encrypted, ${ }^{39}$ encoded ${ }^{40}$ letters. To do this, the agent had to be taught to use the needed chemical in order to retrieve the letters written, ${ }^{41}$ to encrypt and to structure the report, ${ }^{42}$ which also included security features. The letters were sent by the agent

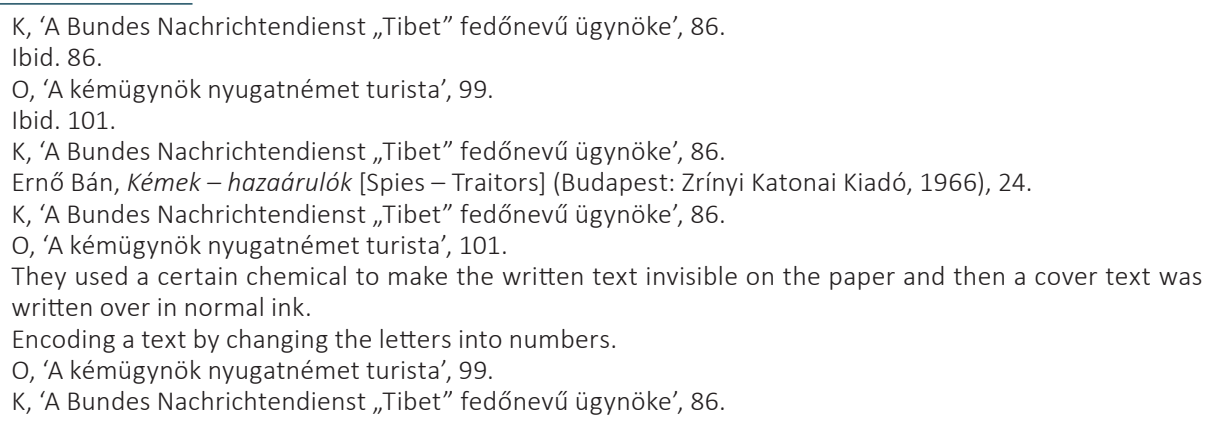


under a cover name to a pre-arranged foreign address. ${ }^{43}$ This method was also used for agent handling, but there were also encrypted messages sent by the intelligence agencies to their agents at a predetermined wavelength and at certain time, which the agent could listen to on his regular radio. However, in some cases, there was a need for personal meeting. In order to be able to use it in all circumstances, they agreed in advance during the training on what password ("Schneider") and/or what sign-object would use the person visiting the agent in order to identify himself. (That sign-object could be a photo, ${ }^{44}$ a pocket knife scratched in a particular place, or even a black woodpecker decorated with silver. ${ }^{45}$ ) Of course, the agent had to have the same sign-object.

Regarding the case studies published in the Review, it is worth noting that the authors of those articles provided details from the investigation in their writings: 'The box of matches has arrived, we are now evaluating it. In the future, we will communicate by encrypted letters. Reduce your reports to 2-3 a year, we will send only one or two letters.'46 (Note: Response from the U.S. intelligence agency to its Hungarian agent, who sent the photocopies of the secret minutes of the spring meeting 1959 COMECON (Council for Mutual Economic Aid) in a matchbox to a safe address.) Another: '...Materials exposed to the intelligence agency, I did not have to get them from elsewhere, these materials were in my possession in the office, they belonged to my field of work. I do not want to bring up the shortcomings of the Ministry's secret case management in my defence, but I had no difficulty in sending those materials - listed in the previous protocol - abroad, because no one would ever look for them, they had no registration.... ${ }^{47}$

Occasionally, the perpetrator's personality was presented and evaluated in the publication, the authors summarised the causes and the circumstances of the crime that made the perpetration possible. ${ }^{48}$ By making the publication interesting, they also helped the Review to achieve the goal of disseminating professional knowledge to the BM (Ministry of the Interior) staff. Taking into account the extremely short period (one or two years) between the case and the publication, it required the permission of the senior professional management and political permission, due to the close relationship between the state party and the state security body.

The case studies published in the Home Affairs Review often provided very detailed information on the intelligence in a given case, but - in protection of the tools and methods - the way in which the case was detected, generally was not mentioned.

Perhaps the multiplication of tasks provided an incentive for the possibility of applying prevention in relation to crimes against the state.

The Act on the Code of Criminal Procedure, ${ }^{49}$ Article 13 adopted in 1962, made the signalisation mandatory for the investigating authorities during criminal proceedings,

T and R, 'Az amerikai hírszerzés „Horváth János” fedőnevű ügynöke', 78.

O, 'A kémügynök nyugatnémet turista', 99.

T and R, 'Az amerikai hírszerzés „Horváth János” fedőnevű ügynöke', 77.

Ibid. 80 .

Józsa, 'Egy nyugatnémet kémügynök ügye', 83.

Ibid. 85.

1962. évi 8. törvényerejű rendelet a büntető eljárásról [The 8th Decree on the Criminal Procedure of 1962]. 
at the same time obliged the notified bodies to provide information within a period of 30 days, in which they had to notify the criminal authority of their adopted preventive measures. In this context, it was suggested that in case of espionage, it would be worthwhile to examine the possibility of signalisation. In the course of proceedings when intelligence activity was detected and proved, state security personnel identified numerous circumstances that made possible the illegal acquirement of a state secret. It is easy to understand that the professional assessment was correct according to which providing information to the organisation in question could have significantly reduced the occurrence of further illegal activities. ${ }^{50}$ In addition to that, the idea of out-of-court signalisation was raised, which on the other hand raised a number of legal issues. The idea of signalisation within the criminal proceedings, would have provided the possibility of sharing relevant information on the certain crime with the personnel of the organisation concerned. ${ }^{51}$ The latter also served the current need of politics, for the sake of winning the society which must be get involved as much as possible in the detection and prevention of crime.

The Home Affairs Review itself also had such a preventive role, as the entire home affairs personnel gained basic knowledge about the espionage, its actors and forms through articles dealing with the field of counter intelligence. Thus, even the traffic policeman could provide information - such as the appearance of a car with a foreign license plate in the vicinity of an object of state security relevance - that could help to detect a case and prevent such acts. The idea of prevention was also served by the fact that lectures were held on counter intelligence ${ }^{52}$ at the law enforcement facilities, and to students (future detectives, political investigators) in the vocational schools of the Ministry of the Interior who studied the history of intelligence as a part of legal studies and as a part of their ideology education. ${ }^{53}$

In addition to the U.S. intelligence services, the Gehlen organisation in the Federal Republic of Germany and its successor, the Federal Intelligence Service (Bundesnachrichtendienst-BND), were the main challenges for the counter intelligence during the examined period. ${ }^{54}$ Certainly for this reason, the knowledge about these intelligence organisations that deserve attention in terms of counter intelligence also appeared on the pages of the Review. With regard to the BND, its responsibilities included intelligence, analysis and information, and also the implementation of 'subversive activities'. It had its own counter intelligence organisation, which was of paramount importance in case another intelligence agency wanted to establish an intelligence position in the BND. The BND relied on German communities living abroad, as well as non-governmental organisations that provided adequate opportunities and coverage to carry out intelligence activities, such as the network of Research

50 Dezsőné Pásztor, 'Az állam elleni búncselekmények megelőzésének néhány kérdése' [Some Questions of the Prevention of Crimes against the State], Belügyi Szemle 2, no 12 (1964), 25.

51 The Constitution Protection Office of Hungary, which accomplishes the tasks of Counter Intelligence, started its Awareness Program almost 60 years later, in 2011.

52 Béla Vincze, 'A parancsnokok közéleti tevéknységéről', [About the Public Life of Commanders], Belügyi Szemle 1, no 1 (1963), 18.

53 János Winkler, 'Világnézeti nevelés a belügyi iskolákon' [Ideological Education in the Schools of the Ministry of the Interior], Belügyi Szemle 4, no 3 (1966), 10.

54 K, 'A Bundes Nachrichtendienst „Tibet” fedőnevű ügynöke', 85. 
Institutes on the East. ${ }^{55}$ The $\mathrm{ClA}$ was also presented, based on an evaluation written of a book, a reminiscent of an 'advertising brochures' in terms of content, by The Profession of Reconnaissance former CIA chief Allen Dulles. The responsibilities of the $\mathrm{ClA}$ included 'espionage, subversion, coups, and political assassinations, defamatory and incentive propaganda'. ${ }^{56}$ The main targets of its intelligence activities were the Soviet Union and socialist countries. As regards the Soviet Union, the primary intelligence requirement was information on the Army: 'We need to know as much as possible about their forces and plans, their military technology, and especially their depots, nuclear bombs, planes and other means of the attack force...' The tools and methods of the CIA included: '...bribery, extortion, lying and slander, eavesdropping on conversations, stealing documents; interception or screening of letters, cryptographic methods...' Overall, the writing criticised the organisation for its almost unlimited power and for its activities threatening peace. He pointed out that some American politicians had also said that the CIA was acting as an 'invisible government'. ${ }^{57}$ The author closed the line with a cynical remark, that in the time of Allan Dulles, the abbreviation CIA was interpreted as 'caught in the action'. ${ }^{58}$ No publications based on information on foreign intelligence agencies were published during the period under examination. The broadening of the horizons of the BM personnel in this field was realised indirectly through knowledge taken from foreign journals, and within the framework of case studies published in the section Lapszemle (Press Review). It is easy to understand why the publishing of our own knowledge could have significantly reduced the effectiveness of the counter activity.

Besides classical intelligence, the disruptive policy pursued by the West also strengthened. The aim of this was to increase social dissatisfaction with the government and the state party in the socialist countries and to strengthen the contradiction between the socialist countries. ${ }^{59}$ In order to achieve this goal, psychological warfare centres were used such as the Radio Free Europe (SZER); 60 the CIA was behind it during this period. According to the Home Affairs, it openly 'instigated' and called on workers to 'oppose' the government's economic policy measures. These changes also 'multiplied' and 'complicated' the tasks of state security agencies. ${ }^{61}$ As regards the 'instigation' crimes within the scope of crimes against the state, the perpetrators listened to the 'hostile, insulting broadcasts' of Radio Free Europe (SZER) on several occasions and committed their actions under its influence. They painted inscriptions

J Mahder, 'A nyugatnémet felderítő szolgálatról' [About the West German Reconnaissance Service], Belügyi Szemle 2, no 8 (1964), 117-120.

56 'Allen Dulles emlékirata' [The Memoirs of Allen Dulles], Belügyi Szemle 2, no 11 (1964), 114.

$57 \quad$ Ibid. 114.

$58 \quad$ bid. 117.

59 Bedő et al., Az imperialisták fellazítási taktikája [Disruptive Tactics of the Imperialists] (Budapest: Kossuth Könykiadó, 1968).

60 István Bekő, 'Az USA lélektani hadviseléséről' [About the Psychological Warfare of the USA], Belügyi Szemle 1, no 5 (1963), 15.

61 László Eperjesi, 'Az MSZMP Központi Bizottsága 1965. november 18-20-i és december 8-i ülésének határozataiból adódó belügyi feladatok' [The Tasks of Law Enforcement after the 8th Session of the Central Committee of the Hungarian Socialist Workers' Party], Belügyi Szemle 4, no 2 (1966), 9. 
on the walls criticising the system, ${ }^{62}$ they made flyers and disseminated them by which they propagated 'hostile propaganda'. ${ }^{63}$ As regards the crimes committed by juveniles, the 'ideological connection with the hostile ideological, disruptive activities of spy and propaganda organisations' almost always could be established. ${ }^{64}$ On the other hand, the responsibility of parents also arose. They listened to the radio with the young people but 'did not enlighten them about the hostility and lies they heard'. ${ }^{65}$ An investigation into a group of juveniles revealed information that 'juveniles, having heard a radio show about spies being "well paid", were determined to present themselves at intelligence agencies in case they get abroad'. ${ }^{66}$

The first publication in the Home Affairs Review, were the thoughts of the Minister of the Interior, János Pap on lawfulness, among the others: 'We have learned from the mistakes of the past and we are not chasing anyone innocent. ${ }^{67}$ In connection with this line, it is worth noting that the crimes against the state, including espionage, ${ }^{68}$ stipulated by the new Criminal Code ${ }^{69}$ adopted in 1961, were described and interpreted in a publication in 1962, and in case of significant changes, compared them with those of the previous Act. ${ }^{70}$ The legislation took a step towards prevention and the 'involvement' of society in crime prevention as a political goal. It was stated that, on the one hand, a Hungarian citizen recruited by a foreign intelligence service cannot be punished if he/she 'voluntarily reports to the authority before commencing intelligence and fully discovers his relationship with the intelligence organisation'.71 On the other hand, if someone becomes aware of preparation for intelligence

62 János Kastyák, 'Feliratos izgatás bűntettének nyomozása a helvéciai állami gazdaságban' [Investigation of Instigation Crime Committed through Inscriptions in a State Farm in Helvécia], Belügyi Szemle 1, no 1 (1963), 88.

Mihály Kada and Kálmán Hegedűs, 'Névtelen fenyegető levelek és izgató röpcédulaterjesztők felderítése' [Detection of Anonymous Letters of Threat and Distributors of Instigating Flyers], Belügyi Szemle 1, no 4 (1963), 102.

Tibor Kása, 'A fiatalkorúak által elkövetett államellenes bűntettek tapasztalatai' [The Experience of Crimes against the State Committed by Juveniles], Belügyi Szemle 2, no 12 (1964), 70.

65 Kastyák, 'Feliratos izgatás bűntettének nyomozása', 88.

66 Kása, 'A fiatalkorúak által elkövetett államellenes bűntettek tapasztalatai', 72.

67 Pap, 'A „Belügyi Szemle” elé...'.

68 1961. évi V. törvény a Magyar Népköztársaság Büntető Törvénykönyvének 131. §-a szerint: 'Aki külföldi kormány, külföldi szervezet vagy ezek megbízottja részére hírszerző tevékenységre ajánlkozik vagy vállalkozik, öt évtől tizenkét évig terjedő szabadságvesztéssel büntetendő. Aki a Magyar Népköztársaság hátrányára felhasználható adatokat abból a célból szerez meg, gyűjt vagy szolgáltat ki, hogy az adat külföldi kormánynak, külföldi szervezetnek vagy ezek megbízottjának tudomására jusson, tíz évtől tizenöt évig terjedő szabadságvesztéssel büntetendő.' [By the terms of Article 131 of the Act on the Criminal Code of the Hungarian People's Republic: 'Anyone who offers to conduct intelligence activity for a foreign government, foreign organisation, or for the representative of those shall be sentenced from five to twelve years of imprisonment. Anyone who obtains, collects or disseminates data in disadvantage of the Hungarian People's Republic in order to inform foreign governments, foreign organisations or their representatives, shall be sentenced from ten to fifteen years of imprisonment.'] 1961. évi V. törvény a Magyar Népköztársaság Büntető Törvénykönyvéről [Act No. 5 of 1961 on the Criminal Code of the Hungarian People's Republic]. Online: www.jogiportal.hu/index.php?id=qko4y25brxtctd8vw\&state=19790414\&menu=view

70 Péter Barna, 'Állam elleni bűntettek az új Btk-ban' [Crimes against the State in the New Criminal Code], Rendörségi Szemle 10, no 3 (1962), 222. 
activity and does not inform the authority 'as soon as he or she can', he or she shell be sentenced to imprisonment. ${ }^{72}$

In addition to legality, another important political call of the period was 'competence', which was in Kádár's quote mentioned in the Home Affairs Review. In order to achieve that goal, and to achieve the required scientific knowledge in the field of home affairs, it would be useful to 'scientifically' process certain cases such as crimes against the state, incitement and conspiracy, related to certain evolutional stages of 'people's democracy', taking into account the foreign and domestic political events and the essential elements of forensic science. It would help to determine the directions and methods of counter actions against these acts, as well as the preventive activity with the involvement of society. ${ }^{73}$ Moreover, there was a need to examine the relationship between individual crimes against the public law and the state, as in several cases it was established that persons involved in intelligence cases, also committed currency offenses in connection with their activities. ${ }^{74}$ Besides, the need was formulated to analyse the personality and background of the perpetrators, especially the recidivists, in order to reduce repeated crimes. ${ }^{75}$ The joint commission of a currency crime and espionage ${ }^{76}$ at that time was understandable due to objective circumstances. Western intelligence agencies paid their agents in foreign currency, but Hungarian citizens had a legal obligation to report the currency in their possession.

According to the Interior Minister's assessment, the society was increasingly supporting state security work by the early 1960s, which was reflected in the agreement to report information indicating crimes ${ }^{77}$ and the agreement to capture intelligence officers. ${ }^{78}$

\section{Summary}

All in all, it can be said that changes took place in Hungary in the early 1960s that had a significant impact on the counter intelligence tasks carried out by the Hungarian state security agencies. The number of challenges had increased and new types of risks had emerged. As a result of the review of the writings in the Internal Affairs Review, it can be established that the Ministry of the Interior tried to present counter intelligence and related areas extensively. In most cases, the writings were not simple statements of facts, but analysis, evaluations and writings that formulated new ideas. Certainly, we cannot ignore the fact that the close party oversight was one of the main features of the period; however, the Home Affairs Review tried to fulfil the function for which it was created.

1961. évi V. tv. 132. § (1) [Article 132, (1) of the Act No. V of 1961].

Tibor Kása, 'Néhány gondolat „A szocialista kriminológia helyzete és programja” című tanulmányhoz' [Some Thoughts on the Study of "The Situation and Programs of Socialist Criminology"], Belügyi Szemle 4, no 1 (1966), 67.

Ibid. 68 .

Ibid. 68.

1961. évi V. törvény, 131. § [Article 131, of the Act No. V of 1961].

Pap, 'A „Belügyi Szemle” elé...', 9.

Ibid. 10. 
JÓZSEF MEZEI: The Appearance of Awareness Related to Counter Intelligence...

\section{References}

1961. évi V. törvény, 131. § [Article 131, of Act No. V of 1961] Online: www.jogiportal. hu/index.php?id=qko4y25brxtctd8vw\&state=19790414\&menu=view

A Magyar Népköztársaság Elnöki Tanácsának 1963. évi 4. számú törvényerejű rendelete a közkegyelem gyakorlásáról [The Statutory Decree of the Presidential Council of the Hungarian People's Republic, Act No. 4 of 1963 on "The Exercise of Public Pardon"]. Online: https://abparancsok.hu/sites/default/files/parancsok/1963.\%20 4tvr.pdf

'Allen Dulles emlékirata' [The Memoirs of Allen Dulles]. Belügyi Szemle 2, no 11 (1964), 114-117.

Bán, Ernő, Kémek - hazaárulók [Spies - Traitors]. Budapest: Zrínyí Katonai Kiadó, 1966.

Bedő, János, Péter Hun, Iván Miklós, Tamás Pálos and András Tardos, Az imperialisták fellazítási taktikája [Disruptive Tactics of the Imperialists]. Budapest: Kossuth Könyvkiadó, 1968.

Békés, Csaba and Gusztáv D Kecskés (eds), A forradalom és a magyar kérdés az ENSZben, 1956-1963: tanulmányok, dokumentumok és kronológia [The Revolution and the 'Hungarian Affair' in the UN, 1956-1963: Essays, Documents and Chronology]. Budapest: Magyar ENSZ Társaság, 2006.

Bekő, István, 'Az USA lélektani hadviseléséről' [About the Psychological Warfare of the USA]. Belügyi Szemle 1, no 5 (1963), 14-22.

Barna, Péter, 'Állam elleni búntettek az új Btk-ban' [Crimes against the State in the New Criminal Code]. Rendőrségi Szemle 10, no 3 (1962), 210-223.

Bozsik, János, 'A BM idegenrendészeti munkájának néhány problémája' [Some Problems of Immigration Work at the Ministry of the Interior]. Belügyi Szemle 4, no 5 (1966), 16-21.

Deák, József, 'A Belügyi Szemle közpolitikai, rendészetelméleti és szerkezeti fejlődése a rendszerváltásig' [Political, Theoretical and Structural Development of the Home Affairs Review until the Change of System]. Hadtudományi Szemle 10, no 2 (2017), 339-355.

Eperjesi, László, 'Az MSZMP Központi Bizottsága 1965. november 18-20-i és december 8-i ülésének határozataiból adódó belügyi feladatok' [The Tasks of Law Enforcement after the $8^{\text {th }}$ Session of the Central Committee of the Hungarian Socialist Workers' Party]. Belügyi Szemle 4, no 2 (1966), 5-10.

Gidáli, Gábor, 'A hazalátogatás lehetőségével visszaélők néhány problémája és a BM szervek feladatai' [Some of the Problems of Those Who Abuse the Opportunity to Visit Home and the Tasks of Home Affairs Bodies]. Belügyi Szemle 4, no 4 (1966), 13-19.

H, P, 'Polarizáció a nyugaton élő magyarság körében' [Polarisation among Hungarians Living in the West]. Belügyi Szemle 1, no 10 (1963), 28-31.

Józsa, Károly, 'Egy nyugatnémet kémügynök ügye' [The Case of a West German Spy]. Belügyi Szemle 2, no 12 (1964), 81-85.

Kada, Mihály and Kálmán Hegedűs, 'Névtelen fenyegető levelek és izgató röpcédulaterjesztők felderítése' [Detection of Anonymous Letters of Threat and Distributors of Instigating Flyers]. Belügyi Szemle 1, no 4 (1963), 102-105. 
Kastyák, János, 'Feliratos izgatás bűntettének nyomozása a helvéciai állami gazdaságban' [Investigation of Instigation Crime Committed through Inscriptions in a State Farm in Helvécia]. Belügyi Szemle 1, no 1 (1963), 83-89.

Kása, Tibor, 'A fiatalkorúak által elkövetett államellenes büntettek tapasztalatai' [The Experience of Crimes against the State Committed by Juveniles]. Belügyi Szemle 2, no 12 (1964), 65-73.

Kása, Tibor, 'Néhány gondolat „A szocialista kriminológia helyzete és programja” című tanulmányhoz' [Some Thoughts on the Study of "The Situation and Programs of Socialist Criminology"]. Belügyi Szemle 4, no 1 (1966), 65-69.

Kobolka, István, Nemzetbiztonsági alapismeretek [Fundamentals of National Security]. Budapest: Nemzeti Közszolgálati és Tankönyvkiadó, 2012.

K, F, 'A Bundes Nachrichtendienst „Tibet” fedőnevü ügynöke' [The Agent of the Bundes Nachrichtendienst under the Cover Name "Tibet"]. Belügyi Szemle 2, no 8 (1964), 85-88.

K, T and J A, 'Egy kémügy tanulságai' [Lessons of a Spy Case]. Belügyi Szemle 2, no 9 (1964), 99-104.

Mahder, J, 'A nyugatnémet felderítő szolgálatról' [About the West German Reconnaissance Service]. Belügyi Szemle 2, no 8 (1964), 117-120.

$\mathrm{O}, \mathrm{Zs}$, 'A kémügynök nyugatnémet turista' [The West German Tourist Spy]. Belügyi Szemle 2, no 7 (1964), 96-102.

Országgyűlési napló [Minutes of Parliament], vol 1, 21 March 1963. Online: https://library.hungaricana.hu/hu/view/OGYK_KN-1963_01/?pg=13\&layout= s\&query=k\%C3\%A9mked\%C3\%A9s

Pap, János, 'A „Belügyi Szemle” elé...' [Preface to the Home Affairs Review]. Belügyi Szemle 1, no 1 (1963), 5-12.

Pásztor, Dezsőné, 'Az állam elleni bűncselekmények megelőzésének néhány kérdése' [Some Questions of the Prevention of Crimes against the State]. Belügyi Szemle 2, no 12 (1964), 24-30.

Pinčukov, E, 'Turistáknak álcázott kémek: nemkívánatos vendégek: kivonatos közlés a „Pogranicsnik” 1965. évi 14. számából' [Spies Disguised as Tourists: Unwanted Guests: Extract from Issue 14 of 1965 of "Pogranichnik"]. Belügyi Szemle 4, no 5 (1966), 120-124.

Szabó, László and János Pap, 'Adalék a rendőrség és a sajtó vitájához: lapjainkról nyilatkozik Pap János a Minisztertanács elnökhelyettese' [Addendum to the Debate between the Police and the Press: János Pap, Deputy Chairman of the Council of Ministers, Comments on our Papers]. Belügyi Szemle 2, no 3 (1964), 72-76.

T, I and L R, 'Az amerikai hírszerzés „Horváth János” fedőnevű ügynöke' [The Agent of the American Intelligence under the Cover Name "János Horváth"]. Belügyi Szemle 2, no 10 (1964), 75-81.

Tímár, István, 'A Magyar Népköztársaság Büntető Törvénykönyvéről' [On the Criminal Code of the Hungarian People's Republic]. Rendörségi Szemle 10, no 1 (1962), 12-21. Vincze, Béla, 'A parancsnokok közéleti tevékenységéről' [About the Public Life of Commanders]. Belügyi Szemle 1, no 1 (1963), 13-20.

Winkler, János, 'Világnézeti nevelés a belügyi iskolákon' [Ideological Education in the Schools of the Ministry of the Interior]. Belügyi Szemle 4, no 3 (1966), 5-14. 